\title{
LO OBJETIVO Y LO SUBJETIVO
}

\author{
Alejandro Llano \\ Universidad de Navarra
}

El concepto clave para la comprensión de la institución universitaria es la verdad. En la verdad se dan cita lo objetivo y lo subjetivo. Pero la articulación de ambas dimensiones queda lejos de una comprensión inmediata. Lo objetivo, por su cuenta, es externo al sujeto cognoscente y, por lo tanto, no puede — por sí sólo- dar cuenta de esa ganancia decisiva que es la verdad. De otra parte, lo subjetivo no trasciende al propio cognoscente $y$, por lo tanto, no incluye ese contraste que resulta clave para que pueda hablarse seriamente de verdad.

Recordemos las famosas preguntas kantianas: ¿Qué puedo conocer? ¿Qué debo hacer? ¿Qué me cabe esperar? Como sabemos, estas tres cuestiones se dan cita, según el propio Kant, en una cuarta interrogación, que tiene la ventaja de trascender lo intencional y apuntar a algo tan real y cercano como somos, para nosotros, nosotros mismos. Esta cuarta pregunta reza así: ¿Qué es el hombre? ¿Qué es el ser humano? ¿Qué soy yo? O mejor: ¿Quién soy yo? Hemos avanzado desde lo teórico y general hacia lo real y concreto: hacia nosotros mismos.

Como dice Millán-Puelles, sólo podemos ser rectos y justos si somos correctos. Sólo podemos ser correctos si lo que pensamos corresponde a la 
verdad de nuestro ser. No puede haber justicia si no comienza a haberla en el hombre y la mujer. Pero en la mujer y el hombre no puede haberla si niegan radicalmente la verdad.

La idea de verdad es paradójica porque, de un lado, es lo más personal, no puede separarse de quien la conoce. No puede, por decirlo así, "andar suelta". Pero, de otro lado, no me pertenece. Sólo existe si es compartida, si en ella se pueden dar cita los sujetos cognoscentes. Tal es la paradoja de la verdad: que es objetiva y subjetiva a un tiempo. Pero se trata de una paradoja que roza lo contradictorio. Y por eso ha sido $-\mathrm{y}$ es- uno de los conceptos más polémicos en toda la historia del pensamiento.

En la verdad está implicado quien la conoce y la dice. De manera que, como señala Ratzinger, el hombre que vive contra la verdad, vive también contra la naturaleza. Lo paradójico del concepto de verdad se hace patente en la expresión de Millán-Puelles, para quien "la verdad es la libre aceptación de nuestro ser”. Tal índole paradójica de la verdad estriba en que sólo se da, que sepamos, en el ser humano. Pero únicamente acontece en él si supera ese enclave. Es quizá el punto en que mejor se hace patente la expresión "el hombre supera infinitamente al hombre".

La única manera de superar estas "paradojas de la verdad" es, sorprendentemente, la de superar las propias vivencias, incluida la propia vivencia de la verdad. Si nos quedamos en lo objetivo o en lo subjetivo, la verdad se nos escapa. Pero, al propio tiempo, no sabemos cómo conciliar lo subjetivo con lo objetivo. Porque lo subjetivo se encierra en sí mismo, mientras que lo objetivo nos supera por todos lados y no somos capaces de atraparlo. 
La verdad sólo se alcanzaría cuando el ser humano trascendiera su propia realidad y saliera fuera de sí mismo, pero sin dejar de ser él mismo. Tendremos que decir, con Bernardo de Claraval que algo semejante — ser interno y externo, subjetivo y objetivo- tendría que constituir "un momento fugaz, un experimento extraordinario". Esta paradoja de la verdad nos acerca al convencimiento de que el ser humano no es un mero producto del medio, de la evolución o de la herencia. Trasciende a su modo lo fácticamente natural y parece remitir a Dios, de un modo más específico y directo que todas las cosas de la naturaleza. No sólo es un ser en el que Dios ha pensado, sino que es un ser que puede pensar a Dios. Dios le quiere y él puede querer a Dios.

Pero acontece que esta extraordinaria peculiaridad del ser humano no sólo es un honor, sino también una carga (honor et honus). Más aún, sólo a través del sufrimiento y de su capacidad para liberarnos de la tiranía del egoísmo, llega a conocerse mejor el hombre: ahí reside su verdad y le cabe acercarse al logro de su vida.

El peligro que hoy nos acecha en las civilizaciones tecnologizadas consiste en el alejamiento del saber originario, en donde la petulancia de una cientificidad mal entendida nos impide oír las instrucciones provenientes de la propia realidad.

No podemos librarnos de las exigencias de una verdad que, paradójicamente, nos supera. La articulación de lo objetivo y lo subjetivo es honor y carga, bonor et onus.

El puro universalismo, la filantropía universal, permanece vacía. Ese universalismo objetivo destruye a la persona real y concreta. Pero la pura 
contraposición a este presunto universalismo —el subjetivismo- es la consagración de la injusticia.

El ser humano no puede comprenderse a sí mismo y a su mundo desde la sola perspectiva del conocimiento. Es el amor el que tiene una tendencia a lo concreto, sin clausurar la apertura a lo universal.

El universalismo de Dios se sirve del particularismo de la historia de la salvación, patente en la figura de Abraham. Desde su mismo inicio, la historia humana es de todos y cada uno. El ser humano comienza de nuevo en cada persona. Es todo lo contrario de lo que dice Hermann Hesse: "Vivir significa estar sólo; nadie conoce al otro". Más lúcido, a su modo, es Albert Camus, quien decía: "Nos miramos y no nos vemos; estamos cerca los unos de los otros y no podemos aproximarnos". De modo que la cuestión que siempre nos asalta se podría formular así: ¿Cómo puedo seguir siendo yo mismo, respetar la alteridad del otro y, con todo, ser capaz de saltar la verja del aislamiento, y tocar al otro por dentro? La verdad es el camino para superar el subjetivismo sin despersonalizarse.

Cuando la tensión hacia la verdad no está presente, se quiebran las relaciones interpersonales, se desintegra el suelo social sobre el que nos apoyamos. La verdad, sin embargo, no puede ser "atópica", no puede existir en un mundo vacío e ilusorio. La verdad es el punto de referencia del dinamismo histórico. Quien se hace a sí mismo señor de la verdad incurre en un error que es al mismo tiempo agresivo e ingenuo. La verdad se sustrae al déspota, al egoísta, al vanidoso. El que pretende constituirse en señor de la verdad es una figura patética. Porque la verdad se abre sólo a quien se aproxima a ella en actitud de reverencia. 


\section{Lo objetivo y lo subjetico}

El ser humano no despliega su ser propio sólo en sí, sino también fuera de sí. Vive en aquellos a los que ama, en aquellos para quienes existe. El yo solo no existe. Pero esto no excluye quererse a sí mismo. La antipatía hacia sí mismo, la incapacidad de aceptarse y reconciliarse consigo propio está muy alejada de la "negación de sí mismo" que pide el Evangelio. Sólo quien se acepta a sí mismo puede aceptar al otro.

Alejandro Llano
allano@unav.es 

ESTUDIOS 
